\title{
An Optimization Decision Support Model for Sustainable Urban Regeneration Investments
}

\author{
P. MORANO ${ }^{1}$, F. TAJANI ${ }^{2}$, C. GUARNACCIA ${ }^{3}$, D. ANELLI ${ }^{2 *}$ \\ ${ }^{1}$ Department of Civil, Environmental, Land, Building Engineering and Chemistry, \\ Polytechnic University of Bari, Via Edoardo Orabona, 4, 70126, Bari, ITALY \\ ${ }^{2}$ Department of Architecture and Design, Sapienza University of Rome, Via Flaminia, 359, 00196, \\ Rome, ITALY \\ ${ }^{3}$ Department of Civil Engineering, University of Salerno, Via Giovanni Paolo II 132, Fisciano (SA), \\ ITALY
}

\begin{abstract}
In order to support the decision-making process related to the reduction of land consumption into the urban regeneration interventions, the present research has the aim to define and propose a goal programmingbased model that can be adopted for the negotiation phases of public and private subjects involved. In particular, the proposed model can provide for a range of feasible scenarios that, according to the specific purposes of the Public Administration, can be implemented in order to achieve the financial, environmental and social level of sustainability targets set by the Agenda 2030. In this way even the private entrepreneur can verify his personal convenience to participate in the investment. Furthermore, the possibility provided by the model to choose a different combination of urban parameters that define the convenience of interventions before their implementation, could reduce the increasingly significant problem of badly concluded interventions, interrupted because they lack an effective ex ante evaluation.
\end{abstract}

Key-Words: - urban investment, urban regeneration, land consumption, soil sealing, goal programming, decision support tool

Received: May 28, 2021. Revised: October 31, 2021. Accepted: November 27, 2021. Published: December 28, 2021.

\section{Introduction}

The rapid development of urban systems has become one of the most faced challenges worldwide. Both academics and decision-makers agree on the need to manage uncontrolled urban expansion - the so-called sprawl - by promoting regeneration and enhancement processes [1]. However, to realize successful initiative it is necessary guaranteeing an improved environmental quality that, at the same time, offers a better livability without restriction on the economic development that is strictly correlated to the constantly evolving needs. It is therefore clear that environmental, social and economic issues are firmly dependent on each other and the variation of one of them born in the cities can have a positive or negative influence on the others [2-3]. This complex condition is also known as the "compact city paradox", due to the conflicting situations which occur into urban dynamics and the difficulty that arises from managing all the specific interests of public and private subjects involved [4].

For these reasons, the concept of "sustainability" of the urban environment began to take shape and spread. It is a multidimensional concept in which the necessity to accomplish the simultaneous aggregation of different conflicting objectives in order to achieve an efficient and feasible solution requires the use of adequate decision support systems [5-7].

Depending on the final outputs provided by the different methods of assessment, determination and quantification of urban sustainability in relation to the reduction of land consumption, the existing approaches can be divided into three main categories: the first one relates to the cognitive analyzes that provide a framework with the criticalities or potentialities of the territory examined, such as reports or cartographic tools based on indicators and maps; the second one consists of operational tools defined to evaluate $e x$ ante sustainability, also in the form of procedures that step by step guide the public and private subject in the analyzes; the third one, finally, contains all the tools that make it possible to quantify and determine specific aspects of sustainability (or all of them), both before and after the intervention, mainly adopting approaches based on systems of synthetic indicators and indices, multi-programming models 
objective, multi-criteria evaluation techniques [816].

Among others, the Goal Programming (GP) technique has been widely applied to address and manage the sustainable urban development decisions, due to its capacity to provide for compromise solutions that takes into account several typology of criteria and the possibility to aggregate often conflicting needs and interests of the subjects considered. Numerous studies have extended the principles of mathematical programming to address specific aspects of sustainability that occur in the urban dynamics. Morano et al. [17] provide for a GP linear model able to identify the most suitable compromise solution among the private entrepreneur and public administration goals by ensuring the environmental features of the regeneration of abandoned areas. Jayamaran et al. [18] study a weighted GP model applied to the key economic sectors of the United Arab Emirates to achieve Sustainable Development Goals (SDG) of the Agenda 2030. San Cristòbal [19] combines economic, energy, social and environmental issues into a GP model based on an environmental inputoutput linear programming in order to define the several goals that must be implemented to achieve sustainability.

As it can be seen, the scale of the analyses carried out in the reference literature varies from the local intervention to a more global vision. The main feature of an effective sustainable development strategy, indeed, is its ability to be scalable -with respect to the territorial context of application- and transversal according to the types of data analyzed and with a true methodology, so as to be able to guarantee its replicability by the decision-makers.

\section{Aim}

The present work is part of the framework outlined. The aim is to define a decision support model that, based on computational logic and principles of GP, can guide public and private subjects involved into urban regeneration investments in the identification of the most sustainable solutions. In particular, the model intends to address three levels of urban sustainability: the first one concerns the financial conveniences of the subject involved, in order to ensure the entire feasibility of the project; the second one regards the environmental degree related to the extent of urban green areas and the limited quantity of natural land take within the project; the third one considers the social aspects with respect to the public services that must be guaranteed to the local community.

The variables from which the most suitable solution derives are those that represent the core urban parameters of the negotiation phases between private and public subjects involved and, at the same time, the same variables determine the morphological structure of the urban regeneration project itself.

The model can be useful to support the public and private subjects involved into the complex decision-making phases of urban regeneration and enhancement processes aimed at improving the sustainability in the long term. Furthermore, it can help the local authorities to achieve the SDGs n.11 and 15 of Agenda 2030, which appear to be the furthest from the targets set by 2050 .

The paper is structured as follows. Section 3 introduces the model by providing a description of the assumptions, the variables, the constraints, and the objective function defined in the proposed model. Section 4 outlines the model's strengths and weaknesses that future research insights might overcome.

\section{Model}

The problem to be addressed is analyzed through a linear programming model which applies the Simplex Algorithm through the Mathematica 9.0 software and with four different typologies of constraints, each one specifically defined to take into account the features of the urban regeneration process and the goals carried out by the two different subjects involved.

\subsection{Assumptions}

The considered subjects are schematized in a generic Public Administration (PA) and a private real estate entrepreneur (PE). Both for the PA and the PE, the financial balance sheets are obtained by considering the costs and the revenues of two different situations: in the first one, the PE realizes only the works related to the private share of the total land plot surface; in the second one, instead, the PE realize both the works on the private share and acquire and reclaim also the share of the total land plot surface to be freely transferred to the PA for public services. The financial conveniences assessment of both of them is carried out as follows: for the PA, they are determined by comparing the realization cost of the public works with the monetary amount of the resources and the buildings freely transferred by the PE for the public 
infrastructures; for the PE, by comparing the revenues generated by the sale of the properties allowed by the urban planning parameters, with the total financial resources that the PE will have to burden for constructing the private properties and the public ones at his expenses.

Three different intended uses and its occupied share of total realizable volumes are assumed. Among the cost items of the PE, its expected remuneration (normal profit) for the activities of production coordination and the risk investment is included. The taxes are not considered in the balance sheets because the aim is to achieve results that focus the attention on the urban initiative parameters, avoiding territory specific-related features that, however, could easily considered and added to the model in future development that pertain to a certain and well-know urban context. For both the balance sheets, the distribution over time of the financial items is not considered, in order to avoid that the uncertainty of the forecasts can affect the final outputs.

\subsection{Variables}

There are nine variables in the model, each one defined according to the general division of private and public shares of the total land plot surface on which the urban regeneration investment has to be realized. A brief description of each variable is following provided:

i. total land plot surface $\left(\mathrm{S}_{\mathrm{tot}}\right)=$ the extent of the areas on which all the works decided for the investment have to be realized;

ii. Private surface $\left(S_{\text {pre }}\right)=$ the share of the total land plot surface $\left(\mathrm{S}_{\mathrm{tot}}\right)$ charged to the PE for the realization of the buildings, greenery and parking works; iii. Private buildings surface $\left(\mathrm{S}_{\mathrm{prb}}\right)=$ the share of the PE total land plot surface $\left(\mathrm{S}_{\mathrm{pre}}\right)$ intended for the construction of the gross floor surface (GFS) allowed by the territorial building volume index $\left(\mathrm{I}_{\mathrm{bt}}\right)$ for the area and planned for the residential $\left(\mathrm{GFS}_{\mathrm{res}}\right)$, offices ( $\left.\mathrm{GFS}_{\text {off }}\right)$ and commercial $\left(\mathrm{GFS}_{\mathrm{com}}\right)$ units;

iv. Green areas surface $\left(\mathrm{S}_{\mathrm{ga}}\right)=$ the share of the PE total land plot surface $\left(S_{\text {pre }}\right)$ where the private green areas will be;

v. Car parking surface $\left(\mathrm{S}_{\mathrm{cp}}\right)=$ the share of the PE total land plot surface $\left(S_{\text {pre }}\right)$ intended for the private car spaces;

vi. Public surface $\left(\mathrm{S}_{\text {pub }}\right)=$ the share of the total land plot surface $\left(\mathrm{S}_{\mathrm{tot}}\right)$ where the PA will carry on the public works;

vii. Public infrastructure surface $\left(S_{\text {pui }}\right)=$ the share of the public total land plot surface $\left(S_{\text {pub }}\right)$ intended for the public services;

viii. Road surface $\left(S_{\text {pur }}\right)=$ the share of the public total land plot surface $\left(S_{\mathrm{pub}}\right)$ where the public roads will be realized;

ix. Freely transferred surface $\left(\mathrm{S}_{\mathrm{tr}}\right)=$ the share of the public total land plot surface $\left(\mathrm{S}_{\mathrm{pub}}\right)$ that the $\mathrm{PE}$ will acquire, reclaim and freely transfer to the PA.

Essentially, $\mathrm{I}_{\mathrm{bt}}$ and $\mathrm{S}_{\mathrm{tr}}$ are the core variables on which the bargaining between the PA and the PE will take place. The other variables are useful to define the constraints of the initiative and to describe the morphological composition of the investment.

\subsection{Constraints}

The proposed model is structured into four different types of constraints described as follows and that can be schematized in the Table 1 .

Table 1. Constraints of the model

\begin{tabular}{|c|c|c|}
\hline Type of constraint & Constraint & Number \\
\hline \multirow{6}{*}{ Physical } & $S_{\text {tot }}=S_{\text {prb }}+S_{\mathrm{ga}}+S_{\mathrm{cp}}+S_{\text {pui }}+S_{\text {pur }}$ & $(1)$ \\
\hline & $\begin{array}{c}S_{\text {pre }}=S_{\text {prb }}+S_{\text {ga }}+S_{c p} \\
S_{\text {pub }}=S_{\text {pui }}+S_{\text {pur }}\end{array}$ & (2) \\
\hline & $\mathrm{GFS}_{\mathrm{tot}}=\mathrm{I}_{\mathrm{tb}} \cdot \mathrm{S}_{\mathrm{tot}}$ & (3) \\
\hline & $\mathrm{GFS}_{\mathrm{tot}}=\mathrm{GFS}_{\mathrm{res}}+\mathrm{GFS}_{\text {off }}+\mathrm{GFS}_{\mathrm{com}}$ & (4) \\
\hline & $\begin{array}{l}\mathrm{GFS}_{\text {res }}=\% \cdot \mathrm{GFS}_{\text {tot }} \\
\mathrm{GFS}_{\text {off }}=\% \cdot \mathrm{GFS}_{\text {tot }} \\
\mathrm{GFS}_{\text {com }}=\% \cdot \mathrm{GFS}_{\text {tot }}\end{array}$ & (5) \\
\hline & $\mathrm{S}_{\mathrm{tr}} \leq \mathrm{S}_{\text {pub }}$ & $(6)$ \\
\hline \multirow{4}{*}{ Project } & $\mathrm{S}_{\mathrm{prb}} \leq \mathrm{R}_{\mathrm{c}} \cdot \mathrm{S}_{\mathrm{tot}}$ & $(7)$ \\
\hline & $\mathrm{GFS}_{\text {tot }} / \mathrm{S}_{\mathrm{prb}} \leq \mathrm{N}_{\mathrm{f}, \max }$ & $(8)$ \\
\hline & $\mathrm{S}_{\mathrm{ga}} \geq \mathrm{a} \cdot \mathrm{S}_{\mathrm{pre}}$ & $(9)$ \\
\hline & $\mathrm{S}_{\text {pur }}=\mathrm{b} \cdot \mathrm{S}_{\mathrm{tot}}$ & $(10)$ \\
\hline Local urban & $\mathrm{S}_{\text {pui,res }}=\mathrm{n}_{\text {inhab }} \cdot 18=\left(\mathrm{GFS}_{\text {res }} / 25\right) \cdot 18$ & $(11)$ \\
\hline
\end{tabular}




\begin{tabular}{|c|c|c|}
\hline \multirow[t]{18}{*}{ planning } & 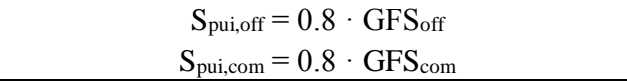 & $(12)$ \\
\hline & $S_{\text {pui }}=S_{\text {pui,res }}+S_{\text {pui,off }}+S_{\text {pui,com }}$ & $(13)$ \\
\hline & $\mathrm{S}_{\mathrm{cp}}=\mathrm{Vol}_{\mathrm{tot}} / 10=\left(\mathrm{GFS}_{\mathrm{tot}} \cdot 3\right) / 10$ & $(14)$ \\
\hline & \multicolumn{2}{|l|}{ Costs } \\
\hline & $\mathrm{K}_{\mathrm{lp}}=\mathrm{k}_{\mathrm{lp}} \cdot\left(\mathrm{S}_{\mathrm{pre}}+\mathrm{S}_{\mathrm{tr}}\right)$ & $(15)$ \\
\hline & $\mathrm{K}_{\mathrm{pt}}=0.15 \cdot \mathrm{K}_{\mathrm{lp}}$ & $(16)$ \\
\hline & $\mathrm{K}_{\mathrm{urb}}=\mathrm{k}_{\mathrm{urb}} \cdot \mathrm{GFS}_{\mathrm{tot}}$ & $(17)$ \\
\hline & $\mathrm{K}_{\mathrm{rec}}=\mathrm{k}_{\mathrm{rec}} \cdot\left(\mathrm{S}_{\mathrm{pre}}+\mathrm{S}_{\mathrm{tr}}\right)$ & $(18)$ \\
\hline & $\begin{array}{c}\mathrm{K}_{\mathrm{bc}, \mathrm{res}}=\mathrm{k}_{\mathrm{cb}, \mathrm{res}} \cdot \mathrm{GFS}_{\mathrm{res}} \\
\mathrm{K}_{\mathrm{bc}, \mathrm{off}}=\mathrm{k}_{\mathrm{cb}, \mathrm{off}} \cdot \mathrm{GFS}_{\text {off }} \\
\mathrm{K}_{\mathrm{bc}, \mathrm{com}}=\mathrm{k}_{\mathrm{cb}, \mathrm{com}} \cdot \mathrm{GFS}_{\mathrm{com}}\end{array}$ & $(19)$ \\
\hline & $\begin{array}{l}\mathrm{K}_{\mathrm{cp}}=\mathrm{k}_{\mathrm{cp}} \cdot \mathrm{S}_{\mathrm{cp}} \\
\mathrm{K}_{\mathrm{ga}}=\mathrm{k}_{\mathrm{ga}} \cdot \mathrm{S}_{\mathrm{ga}}\end{array}$ & $(20)$ \\
\hline & $\mathrm{K}_{\mathrm{ta}}=0.05 \cdot \mathrm{K}_{\mathrm{bc}}$ & $(21)$ \\
\hline & $\mathrm{K}_{\operatorname{man}}=0.04 \cdot \mathrm{K}_{\mathrm{bc}}$ & $(22)$ \\
\hline & $\mathrm{K}_{\mathrm{mar}}=0.02 \cdot \mathrm{R}_{\mathrm{tot}}$ & $(23)$ \\
\hline & $\mathrm{K}_{\text {transf }}=\mathrm{K}_{\mathrm{bc}}+\mathrm{K}_{\mathrm{lp}}+\mathrm{K}_{\mathrm{pt}}+\mathrm{K}_{\mathrm{urb}}+\mathrm{K}_{\mathrm{ta}}+\mathrm{K}_{\mathrm{man}}+\mathrm{K}_{\mathrm{mar}}$ & $(24)$ \\
\hline & $\mathrm{K}_{\mathrm{fc}}=0.06 \cdot \mathrm{K}_{\text {transf }}$ & $(25)$ \\
\hline & $\mathrm{K}_{\text {profit }}=0.20 \cdot \mathrm{R}_{\mathrm{tot}}$ & $(26)$ \\
\hline & \multicolumn{2}{|l|}{ Revenues } \\
\hline & $\begin{aligned} \mathrm{R}_{\text {res }} & =\mathrm{r}_{\mathrm{res}} \cdot \mathrm{GFS}_{\text {res }} \\
\mathrm{R}_{\mathrm{off}} & =\mathrm{r}_{\mathrm{off}} \cdot \mathrm{GFS}_{\text {off }} \\
\mathrm{R}_{\mathrm{com}} & =\mathrm{r}_{\mathrm{com}} \cdot \mathrm{GFS}_{\mathrm{com}} \\
\mathrm{R}_{\mathrm{cp}} & =\mathrm{r}_{\mathrm{cp}} \cdot \mathrm{S}_{\mathrm{cp}}\end{aligned}$ & $(27)$ \\
\hline \multirow{5}{*}{$\begin{array}{c}\text { Financial for the } \\
\text { PA }\end{array}$} & \multicolumn{2}{|l|}{ Costs } \\
\hline & $\mathrm{K}_{\mathrm{lp}}+\mathrm{K}_{\mathrm{rec}}=\left(\mathrm{k}_{\mathrm{lp}}+\mathrm{k}_{\mathrm{rec}}\right) \cdot\left(\mathrm{S}_{\mathrm{pub}}\right)$ & $(28)$ \\
\hline & \multicolumn{2}{|l|}{ Revenues } \\
\hline & $\mathrm{K}_{\mathrm{urb}}=\mathrm{k}_{\mathrm{urb}} \cdot \mathrm{GFS}_{\mathrm{tot}}$ & $(29)$ \\
\hline & $\mathrm{K}_{\mathrm{mis}}=\left(\mathrm{k}_{\mathrm{lp}}+\mathrm{k}_{\mathrm{rec}}\right) \cdot \mathrm{S}_{\mathrm{tr}}$ & $(30)$ \\
\hline
\end{tabular}

The physical constraints (from n.1 to n.6 of Table 1) pertain to the articulation and subdivision of the total land plot into the share intended for the different land uses and works established. The project constraints (from n. 7 to n.10 of Table 1) refer to $i$ ) the general urban planning rules that must be applied according to the coverage ratio of the total property surface $\left(\mathrm{R}_{\mathrm{c}}\right)$, ii) the maximum number of floors $\left(\mathrm{N}_{\mathrm{f}, \max }\right)$ achievable; $a$ and $b$ are two coefficients between 0 and 1 , which determine the share respectively intended for green areas and public roads. For the local urban planning constraints (from n.11 to n.14 of Table 1) the infrastructure required for the number of inhabitants $\left(\mathrm{n}_{\text {inhab }}\right)$ is calculated for each intended use according to provisions of the Italian Ministerial Decree No. 1444/68; the extent of surface for the car parking spaces is set by total building volumes $\left(\mathrm{Vol}_{\text {tot }}\right)$, i.e. with reference to Italian Law No. 122/1989. Moreover, it is assumed that each floor of new buildings has an average height of 3 meters. The costs and revenues items that represent the PE and PA financial constraints are described in the following Table 2.

Table 2. Description of costs and revenues items considered for the PE and PA financial constraints.

\begin{tabular}{l|l}
\hline $\begin{array}{l}\text { Cost of land plot } \\
\text { acquisition }\left(\mathrm{K}_{\mathrm{lp}}\right) \\
(\text { Eq.15) }\end{array}$ & $\begin{array}{l}\text { Determined by applying the unit market value }\left(\mathrm{klp}, € / \mathrm{m}^{2}\right) \\
\text { to the extent of the building areas. }\end{array}$ \\
\hline $\begin{array}{l}\text { Property transfer } \\
\text { expenses }\left(\mathrm{K}_{\mathrm{pt}}\right)\end{array}$ & $\begin{array}{l}\text { Calculated as } 10 \% \text { of the total purchase price of plot and } \\
\text { including the registration and notary expenses. }\end{array}$ \\
\hline $\begin{array}{l}\text { Urbanization fees } \\
\left(\mathrm{K}_{\text {urb }}\right)(\text { Eq.17) }\end{array}$ & $\begin{array}{l}\text { Quantified by applying the unit values }\left(€ / \mathrm{m}^{2}\right) \text { reported in } \\
\text { the municipal tables according to the intended uses. }\end{array}$ \\
\hline
\end{tabular}




\begin{tabular}{|c|c|}
\hline $\begin{array}{l}\text { Reclamation cost } \\
\left(\mathrm{K}_{\mathrm{rec}}\right)(\text { Eq.18) }\end{array}$ & $\begin{array}{l}\text { Works to optimize soil surface are determined by } \\
\text { multiplying the unit cost }\left(\mathrm{k}_{\mathrm{rec}}, € / \mathrm{m}^{2}\right) \text { and the extent of } \\
\text { surfaces. }\end{array}$ \\
\hline $\begin{array}{l}\text { Construction cost } \\
\left(\mathrm{K}_{\mathrm{bc}}\right)(\text { Eq.19) }\end{array}$ & $\begin{array}{l}\text { Parametric construction cost }\left(\mathrm{kbc}, € / \mathrm{m}^{2}\right) \text { determined } \\
\text { according to the different allowed intended uses. }\end{array}$ \\
\hline $\begin{array}{l}\text { Parking }\left(\mathrm{K}_{\mathrm{cp}}\right) \text { and } \\
\text { green private spaces } \\
\left(\mathrm{K}_{\mathrm{ga}}\right) \text { construction } \\
\text { cost (Eq.20) }\end{array}$ & $\begin{array}{l}\text { Parametric unit cost }\left(\mathrm{k}_{\mathrm{cp}} \text { and } \mathrm{kga}_{\mathrm{ga}} € / \mathrm{m}^{2} \text { ) based on similar }\right. \\
\text { works or the price list of relevant institutions. }\end{array}$ \\
\hline $\begin{array}{l}\text { Technical expenses } \\
\left(\mathrm{K}_{\mathrm{ta}}\right)(\text { Eq. } 21)\end{array}$ & $\begin{array}{l}\text { The fees for technicians determined as a percentage of } 5 \% \\
\text { of the sum of total construction costs. }\end{array}$ \\
\hline $\begin{array}{l}\text { General expenses } \\
\left(\mathrm{K}_{\mathrm{man}}\right)(\mathrm{Eq} .22)\end{array}$ & $\begin{array}{l}\text { The management activities are calculated as a percentage } \\
\text { of } 4 \% \text { of the sum of the total construction costs. }\end{array}$ \\
\hline $\begin{array}{l}\text { Commercialization } \\
\text { fees }\left(\mathrm{K}_{\mathrm{mar}}\right)(\text { Eq. } 23)\end{array}$ & $\begin{array}{l}\text { Equal to } 2 \% \text { of the market value of the final buildings. } \\
\text { They are intended for the marketing of them. }\end{array}$ \\
\hline $\begin{array}{l}\text { Financial fees }\left(\mathrm{K}_{\mathrm{fc}}\right) \\
(\text { Eq.25) }\end{array}$ & $\begin{array}{l}\text { Set equal to } 6 \% \text { of the total transformation cost }\left(\mathrm{K}_{\text {transf, }}\right. \\
\text { Eq.24). They identify the interest on capital borrowed for } \\
\text { the project. }\end{array}$ \\
\hline $\begin{array}{l}\text { Normal Profit }\left(\mathrm{K}_{\text {profit }}\right) \\
\text { (Eq.26) }\end{array}$ & $\begin{array}{l}\text { The expected remuneration of the PE is set equal to } 20 \% \\
\text { of the estimated revenues from the selling phase. }\end{array}$ \\
\hline $\begin{array}{l}\text { Transformation } \\
\text { revenues (R) (Eq 27) }\end{array}$ & $\begin{array}{l}\text { The revenues from the sale of the GFS of each intended } \\
\text { use are obtained by multiplying the unit selling prices } \\
\left(€ / \mathrm{m}^{2}\right) \text { and its extent of them. }\end{array}$ \\
\hline $\begin{array}{l}\text { Infrastructure } \\
\text { contribution fees } \\
\text { (Eq.28) }\end{array}$ & $\begin{array}{l}\text { Unitary parametric values }\left(€ / \mathrm{m}^{2}\right) \text { fixed by the } \\
\text { municipality. }\end{array}$ \\
\hline $\begin{array}{l}\text { Acquisition and } \\
\text { reclamation of areas } \\
\text { for the public works } \\
\text { (Eq.29) }\end{array}$ & $\begin{array}{l}\text { Estimated using unit price }\left(\mathrm{k}_{\mathrm{pl}}\right) \text { and unit reclamation cost } \\
\left(\mathrm{k}_{\mathrm{rec}}\right) \text { found on the local market for the acquisition and } \\
\text { reclamation of the areas intended for public works. }\end{array}$ \\
\hline $\begin{array}{l}\text { Opportunity costs of } \\
\text { PA (Kmis, Eq.30) }\end{array}$ & $\begin{array}{l}\text { They identify values of areas }\left(\mathrm{S}_{\mathrm{tr}}\right) \text { that PE is required to } \\
\text { purchase, reclaim and freely transfer to PA by applying the } \\
\text { unit selling price and reclamation cost of the local market. }\end{array}$ \\
\hline
\end{tabular}

\subsection{Objective Function and Algorithm of the Model}

In order to define the best range of solutions that can help PA and PE in identifying the combination of urban parameters on which the benefits of each of them depend, a complex objective function is proposed. It involves the maximization of the surface that the PE has to transfer to the PA for the public works $\left(S_{\mathrm{tr}}\right)$ and the extent of the green areas $\left(\mathrm{S}_{\mathrm{ga}}\right)$ with the simultaneous minimization of land take surface (represented by the $\mathrm{I}_{\mathrm{bt}}$ ) of the urban project. The algorithm of the defined model is reported in Table 3.

Table 3. Algorithm of the model

\begin{tabular}{c|c}
\hline Variables & $\mathrm{I}_{\mathrm{bt}}, \mathrm{S}_{\mathrm{prb}}, \mathrm{S}_{\mathrm{ga}}, \mathrm{S}_{\mathrm{tr}}$ \\
Objective function & Max! (wStr $\left.\cdot \mathrm{S}_{\mathrm{tr}}+\mathrm{wSga}_{\mathrm{gga}} \cdot \mathrm{S}_{\mathrm{ga}}-\mathrm{w}_{\mathrm{Igt}} \cdot \mathrm{I}_{\mathrm{gt}}\right)$ \\
Type of constraints & Physical (see Table 1) \\
& Project (see Table 1) \\
& Urban Planning (see Table 1) \\
& Financial (see Table 1) \\
\hline
\end{tabular}


The importance of each variable of the objective function is taking into account by adding the weights $\left(\mathrm{w}_{\text {Str }}, \mathrm{w}_{\text {Sga }}, \mathrm{w}_{\text {Igt }}\right)$ that can vary from 0 to 2 in order to provide a range of different solutions that identify a set of feasible set of scenarios that can be chosen, according to the specific needs pursued by the PA.

\section{Conclusions}

The cities are considered as the place where the most significant dynamics occur, in terms of natural, social, and economic changes. However, the uncontrolled urban expansion is a phenomenon which has already affected a significant share of the existing ecosystem sphere. These contingences have raised up the necessity to adopt and implement adequate decision support tools, able to provide efficient management and feasible solutions, in order to achieve the sustainable development targets, set by the Agenda 2030 and the other existing directives.

Aim of the work has been to provide for a decision support model that public and private subjects involved in the decision-making process of urban regeneration and enhancement investments can use for identifying the most suitable compromise solution among financial, environmental, and social interests. In particular, the proposed model has the advantages i) to provide a series of easily understandable feasible scenarios, ii) to be flexible both in terms of constraints and objectives, iii) objectify and systematize the complex process of urban sustainability, $i v$ ) keep account of the different and conflicting intentions carried out by PA and PE.

Future insights of the present research could concern the application of the model to a real case study, also by integrating the "static" mathematical structure with the Cost-Revenues Analysis technique in order to take into account the effects of the time in the evaluation.

\section{References:}

[1] Artmann, M., Inostroza, L., \& Fan, P.2019 Urban sprawl, compact urban development and green cities. How much do we know, how much do we agree? Ecological Indicators Vol 2 Issue 96 pp 3-9

[2] Nechi, S., Aouni, B., \& Mrabet, Z. 2020 Managing sustainable development through goal programming model and satisfaction functions Annals of Operations Research 293(2) pp 747-766
[3] Nguyen, H. M. 2018 The relationship between urbanization and economic growth: An empirical study on ASEAN countries International Journal of Social Economics Vol 45 Issue 2 pp 316-339

[4] De Roo, G., 2000 Environmental conflicts in compact cities: complexity, decision making, and policy approaches Environ. Planning B: Plan. Des. 27 pp 151-162

[5] Neuman, M., 2005 The Compact City Fallacy J. Plan. Educ. Res. 25 11-26

[6] Nesticò, A., Endreny, T., Guarini, M. R., Sica, F., \& Anelli, D. 2020 Real Estate Values, Tree Cover, and Per-Capita Income: An Evaluation of the Interdependencies in Buffalo City (NY) International Conference on Computational Science and Its Applications pp 913-926 Springer Cham

[7] Morano, P., Tajani, F., Di Liddo, F., \& Anelli, D. 2020 A feasibility analysis of the refurbishment investments in the Italian residential market Sustainability Vol 12 Issue 6 pp 2503

[8] Hansuebsai, A., Kaosod, A., \& Kanchanasing, T. 2020 A new environmental performance index based on the carbon footprint, VOC emissions, and waste in a printing house Engineering Reports Vol 2 Issue 5

[9] Richter, B., \& Behnisch, M. 2019 Integrated evaluation framework for environmental planning in the context of compact green cities Ecological indicators Vol 96 pp 38-53

[10] Jeong, J.S. 2018 Design of spatial PGISMCDA-based land assessment planning for identifying sustainable land-use adaptation priorities for climate change impacts Agricultural Systems Vol 167 pp 61-71

[11] Li, Z., Liu, Q., Tang, J., Ran, Y. and Ke, D. 2018 Analysis and evaluation of urban land use 2018 7th International Conference on Energy, Environment and Sustainable Development (ICEESD 2018) Atlantis Press

[12] Nguyen, T.T., Verdoodt, A., Van, Y.T., Delbecque, N., Tran, T.C. and Van Ranst, E. 2015 Design of a GIS and multi-criteria based land evaluation procedure for sustainable land-use planning at the regional level Agriculture, Ecosystems and Environment Vol 200 pp 1-11

[13] Gómez, J.M.N., Castanho, R.A., Velarde, J. G. 2021 Studying the occupied urban land development in portugal mainland between 1990-2018 WSEAS Transactions on Environment and Development Vol 17 pp 
1053-1063

[14] Zapata, V. Y. H., Zabala, F. J. V., \& Martínez, M. A. 2019 Sociodemographic, Cultural, Environmental and Agroecological Characterization in Order to Adopt Urban Agriculture in the Municipality of Tuluá, Colombia International Journal of Agricultural Science Vol 4

[15] Guijarro, F., \& Poyatos, J. A. 2018 Designing a sustainable development goal index through a goal programming model: The Case of EU28 Countries Sustainability Vol 10 Issue 9 pp 3167

[16] Blancas, F. J., Caballero, R., González, M., Lozano-Oyola, M., \& Pérez, F. 2010 Goal programming synthetic indicators: An application for sustainable tourism in Andalusian coastal counties Ecological Economics Vol 69 Issue 11 pp 2158-2172

[17] Morano, P., Tajani, F., \& Anelli, D. 2020 Urban planning decisions: An evaluation support model for natural soil surface saving policies and the enhancement of properties in disuse Property Management Vol 38 Issue 5 pp 699-723

[18] Jayaraman, R., Colapinto, C., La Torre, D., \& Malik, T. 2015 Multi-criteria model for sustainable development using goal programming applied to the United Arab Emirates Energy Policy,87, 447-454

[19] San Cristóbal, J. R. 2012 A goal programming model for environmental policy analysis: Application to Spain Energy Policy, 43, pp 303-307

\section{Creative Commons Attribution License 4.0} (Attribution 4.0 International, CC BY 4.0)

This article is published under the terms of the Creative Commons Attribution License 4.0 https://creativecommons.org/licenses/by/4.0/deed.e $\underline{\text { n US }}$ 